\title{
Malheureusement, faute de poste, son autrice a dû changer de métier
}

Revues en lutte

\section{CpenEdition}

Journals

Édition électronique

URL : http://journals.openedition.org/pa/851

DOI : 10.4000/pa.851

ISSN : 2273-0362

Éditeur

Université Lumière Lyon 2

Référence électronique

Revues en lutte, " Malheureusement, faute de poste, son autrice a dû changer de métier », Parcours anthropologiques [En ligne], 14 | 2020, mis en ligne le 19 mars 2020, consulté le 04 septembre 2020. URL : http://journals.openedition.org/pa/851 ; DOI : https://doi.org/10.4000/pa.851

Ce document a été généré automatiquement le 4 septembre 2020

Parcours anthropologiques 


\section{Malheureusement, faute de poste, son autrice a dû changer de métier}

Revues en lutte

\section{Revues en lutte}

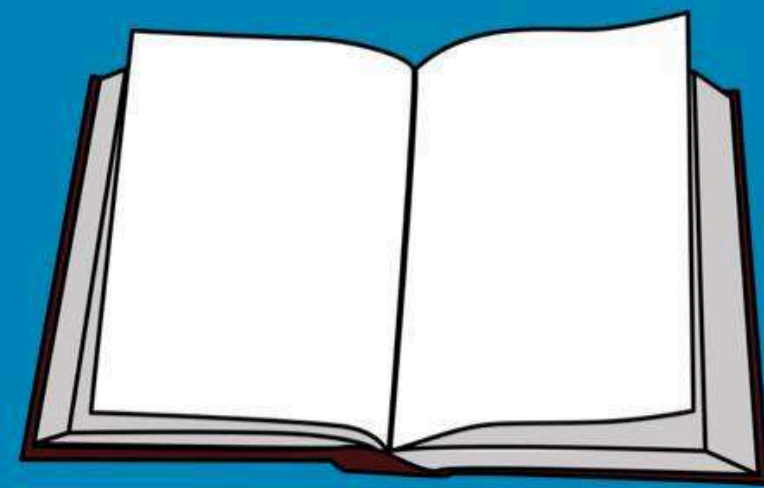

Ici, vous auriez pu lire un article scientifique de haut niveau. Nalheureusement, faute de poste, son autrice a dû changer de métier avant de l'avoir écrit... 